\title{
Employee Turnover in a Regional Commercial Bank
}

\author{
C. Pietersen \\ Department of Business Management, Human Resource Management Programme, University of Limpopo, \\ Turfloop Campus, Sovenga 0727, South Africa \\ charlotte.pietersen@ul.ac.za \\ O. A. Oni
Department of Business Management, University of Limpopo, Turfloop Campus, Sovenga, 0727, South Africa
olabanji.oni@ul.ac.za
}

Doi:10.5901/mjss.2014.v5n27p371

\section{Abstract}

This study explored employee turnover in a commercial bank in Limpopo Province, South Africa. Apparently there is a need to curb dysfunctional mobility of human capital in the banking sector in the region. A cross-sectional mixed method design was used to collect data. A stratified sample of banking employees completed a semi-structured questionnaire. Key informant interviewing and a focus group discussion were employed to gather supplementary data. Archival data was used in the calculation of turnover rates. The results show a relatively low overall employee turnover rate, and differences in turnover rates for different job levels and gender distributions. The turnover rate for older and young employees is relatively similar. Factors that contribute to job dissatisfaction include better job offers elsewhere, poor compensation, a lack of promotional opportunities, and Black Economic Empowerment initiatives. The findings of the study provide evidence of the most pressing turnover problems that a bank in a less affluent geographic region experiences. The impact of job dissatisfaction on the productivity, efficiency and service delivery in the bank is highlighted and a number of human resource practices are recommended to manage employee and to develop much needed human capital in the banking sector in the region.

Keywords: Employee turnover rates; voluntary turnover; demographic variables; job dissatisfaction; hygiene factors

\section{Introduction}

Employee turnover in the banking sector in South Africa has come under the spotlight in the last decade. Research findings show that the banking sector worldwide as well as in South Africa is characterized by high employee turnover and skill shortages (Metcalfe, 2011; Springer, 2011). It could therefore be argued that the sector also experiences high employee turnover in Limpopo Province, one of the nine provinces in South Africa. One important factor that could probably contribute to this trend is that the province, a largely rural region with a pressing need for sustained social and economic development, has to compete for talent with more well-to-do provinces, in particular it nearest neighbour, Gauteng Province (Radebe, 2009). It is estimated that 14 percent of males and 11.6 percent of females employed in the financial sector in Gauteng are in-country migrants. Furthermore, the largest number employees who relocate to Gauteng come from Limpopo, accounting for 9.8 percent of all migrants to Gauteng (Oosthuizen \& Naidoo, 2004).

South African banking CEOs have acknowledged that the availability of skills, a component of human capital/talent, is a key issue for banks (Grosskopf \& Atherman, 2011). The retention of employees, the font of human capital in an organization, could therefore be a major challenge facing banks in Limpopo Province. Approximately 3.5 percent of the economically active population in Limpopo is qualified to do highly-skilled labour while approximately 76 percent are only qualified for unskilled and semi-skilled labour (Limpopo Growth and Development Strategy, 2004-2014). It would appear that banks in the province have to pull out all stops to retain human capital, improve skill levels and attract talent to relocate to the province.

The aim of the present study is to explore turnover among employees in the banking sector in Limpopo Province, South Africa. The objectives of the study are to determine the extent of employee turnover; identify specific causes of employee turnover; recommend retention practices to manage employee turnover. 


\section{Literature Review}

\subsection{Voluntary and involuntary employee turnover}

Zeki, Engin \& Selim (2012: 107) define human capital as the stockpile of employee knowledge, attitudes, abilities, technical skills, creativity and experience that exist within an organization at a given point in time. A key factor that affects the flow of human capital or talent through an organization is employee mobility. Human capital has more mobility than any other asset (Ballester, Livnat \& Sinha, 2002). An organization will only be able to sustain a competitive advantage if it manages employee mobility effectively.

Unfortunately, employee mobility cannot always be controlled by an organization. In this regards employee turnover - the voluntary or involuntary movement employees in an out of work organizations - is of key importance in talent management. It is therefore not surprising that the management of employee turnover (voluntary well as involuntary turnover) continues to be a central concern in the management literature. It is a key concern for both profit and non-profit organizations (Choi \& Lee, 2011: 91).

Voluntary turnover is initiated by an employee and involuntary turnover by an employer (Choi, Musibau, Khalil \& Ebi, 2012). Involuntary turnover also result from uncontrollable factors such as death and ill health. Functional voluntary and involuntary turnover could benefit an organization. For example, according to Archer (2008), employee turnover at lower organizational levels could be beneficial to banks because advances in technology continue to reduce the need for lower level skills in the banking sector. On the other hand, the need for non-manual, intermediate and high level skills as well as value-adding competencies such as autonomy and discretion are on the increase in the banking sector (Archer, 2008). Therefore, both voluntary and involuntary turnover could be dysfunctional if the result is a loss of human capital (Campbell, Coff \& Kryscynski, 2012). In addition, dysfunctional employee turnover in banks 'leads to the loss of the tacit knowledge possessed by leavers' (Amah, 2009: 24).

Another reason why employee turnover continues to be of key importance for organizations is that the movement of employees in and out of an organization has direct financial implications for the organization. Organizations have to make provision for separation and replacement costs (including staffing and training costs) when voluntary and/or involuntary employee turnover occur (Abbasi \& Hollman, 2000; Griffith \& Horn, 2001). In addition, research findings show that dysfunctional employee turnover, in particular voluntary turnover, impacts negatively on, among others, business performance and organizational effectiveness (Shaw, Gupta \& Delery, 2005; Tariq, Ramzan \& Riaz, 2013) as well as employee commitment and customer satisfaction (Sing \& Loncar, 2010; Wang, Yang \& Wang, 2012). It is therefore imperative to reduce turnover rates in order to reduce separation and replacement costs and to enhance employees' loyalty and commitment to an organization which in turn could lead to better organizational performance.

\subsection{Employee turnover drivers}

Research findings indicate that both job satisfaction and job dissatisfaction could result in voluntary employee turnover (Griffith, Horn \& Gaertner, 2000; Shahzad, Hayat, Abbas \& Bashir, 2011; Yücel, 2012). Annual surveys conducted by the Chartered Institute of Personnel and Development (CIPD) have shown consistently that the majority of employee turnover is attributed to voluntary turnover (CIPD, 2004). Moreover, South African banking CEOs have indicated that the management of job dissatisfaction is crucial to attract, retain and reward high quality employees in their organizations (Archer, 2008).

Porter and Steers (1973) compiled what they termed an 'expectation set' to divide the causes of turnover into four groups of factors. These groups are personal, organization-wide, work-environmental and job-related factors. The two scholars make use of the concept of 'met expectations' to explain employee turnover. Long, Ajagbe, Nor and Suleiman (2012: 284) define the concept of met expectations as a discrepancy between what a person encounters on a job in the form of positive and negative experiences and what he or she expects to encounter. A person will be inclined to leave when his or her expectations are not being met. An individual's job satisfaction or dissatisfaction also depends upon the extent to which one perceives that one's needs are being met.

Job satisfaction is defined as 'a positive or pleasurable affective response resulting from the appraisal of various facets of one's job or job experiences' (Kasimati, 2011: 321). According to Herzberg's classic motivation-hygiene theory, intrinsic motivators lead to job satisfaction (Herzberg, Mausner \& Snyderman, 1959). These motivators include the nature of the work itself, recognition, autonomy, a sense of achievement, and personal growth and advancement. They gratify needs for achievement, competency, status, personal worth and self-realization. Job dissatisfaction on the other hand results from an unfavourable assessment of 'hygiene factors'. Hygiene factors include compensation, job security, 
working conditions, company policies and administration, supervision and interpersonal relations. They are extrinsic to a job itself and lead to dissatisfaction if an individual has negative affective responses to one or more of them (Herzberg, 1968).

Organization wide causes of employee turnover include Herzberg's hygiene factors such as development/training and promotion policies, compensation, working conditions, working hours and job security (Allen, 2008). Previous research findings have indicated that dissatisfaction with human resource policies, career advancement opportunities, and compensation packages (pay and benefits) are negatively associated with employee turnover (Grissom, NicholsonCrotty \& Keiser, 2012; Ito, 2003). Job insecurity could also lead to movement to an alternative job when better opportunities are offered by other employers (Walsh \& Taylor, 2007).

Work-environment hygiene factors that could lead to employee turnover include the quality of supervisor and coworker relations. Both factors are related to job dissatisfaction and turnover of employees (Bertelli, 2007; Seymour \& Buscherhof, 1991; Sulaiman \& Ogunsina, 2011).

Job related causes of low job satisfaction and employee turnover include intrinsic motivators (the nature of job requirements, autonomy, challenging work and a sense of achievement), as well as job stress and feedback (Kasimati, 2011; Sulaiman \& Ogunsina, 2011). Employees will leave when better growth opportunities and more challenging job are offered by other organizations (Houkes, Janssen, De Jong \& Bakker, 2003).

Personal factors that could cause employee turnover include factors such as age, gender and job level. Voluntary turnover among younger employees tend to be higher compared to older long serving employees (Kabungaidze, Mahlatshana \& Ngirande, 2013). In general, the turnover rate for females is higher than the voluntary turnover rate for males. This tendency is largely attributed the family and child care responsibilities and a lack of career advancement/promotional opportunities (Cotton \& Tuttel, 1986; Nel, Van Dyk, Haasbroek, Schultz, Sono \& Werner, 2011). Job levels also impact on employee turnover. One possible reason is that employees in lower job categories find their jobs less financially and psychologically rewarding compared to employees at higher organizational levels (Kellough \& Haoran, 1993; Nel, Erasmus \& Swanepoel, 2001).

\subsection{Managing employee turnover}

Although external causes of employee turnover such as labour supply and demand and the availability of alternative jobs (Harman, Blum, Stefani \& Taho, 2009) as well as involuntary turnover cannot be controlled by an organization, they have to plan strategically to minimize the effects of such forms of turnover in the future. One way to manage transactional costs associated with involuntary turnover is to redesign jobs or organizational processes (Meier \& Hicklin, 2008).

On the other hand, the internal causes of employee turnover can be managed to a large extent (Allen, 2008). Organizations could employ different retention strategies to increase employee job satisfaction and minimize dissatisfaction (Liu, Mitchell, Lee, Holtom \& Hinkin, 2012). A number of human resource practices can be used to increase job satisfaction and decrease job dissatisfaction. These include better staffing practices, training and development, competitive compensation and better supervision (Allen, 2008). An organisation should also develop a wellinformed retention policy (Kim, 2012) that is aligned with its other human resource policies and the strategic business objectives of an organization.

Staffing practices that could be used to increase job satisfaction include job redesign, recruitment, selection and induction.

(a) Job enrichment and job rotation can be used to increase job satisfaction by providing more task significance, autonomy and variety to an employee (Allen, 2008).

(b) The use of an internal recruitment strategy to promote employees from within an organization could also be considered. Organizations that allow greater internal opportunities for advancement are more successful at retaining employees (Nel, et al., 2011).

(c) Job selection should be vacancy specific and focused on job requirements (Van der Merwe \& Miller, 1993). Furthermore, biographical data used in selection provides an indication of tenure in previous jobs and could be seen as predictive of turnover intention in the future (Griffith \& Horn, 2001).

(d) Good induction and the use of a realistic job preview (RJP) could also increase tenure in an organization (Breaugh \& Starke, 2000; Kammeyer-Mueller \& Wanberg, 2003). The use of a realistic job preview (RJP) reduces the discrepancy between a new young employee's initial expectations and unmet job expectations which in turn could reduce turnover (Hom, Griffeth \& Sellaro, 1984).

Interventions focused on empowering employees could be used to decrease job dissatisfaction. It is generally accepted that training and development interventions to enhance skills as well as managerial competencies will reduce 
job dissatisfaction and boost employee retention (Allen, Shore \& Griffeth, 2003; Rhoades \& Eisenberger, 2002; Sherman \& Bohlander, 1992; Sing, 2012). However, training and development should be considered carefully. The development of general and transferable skills may in fact increase turnover. Research findings show that these skills increase employees' external marketability and mobility (Haines, Jalette \& Larose, 2010). Allen (2008) recommends that in order to retain employees, job-specific training should be provided.

The development of supervisory skills and competencies remain of particular importance because the quality of supervision could play a key role in the reduction job dissatisfaction and employee turnover. Supervisors have to manage physical and psychological working conditions (such as work overload or work underload, working hours and unmet expectations) in their departments. The effective management of these factors could decrease job dissatisfaction (Nel, et al, 2011; Shahzad et al., 2011). Coaching and training should be considered to develop the planning, organizing, directing and controlling skills of supervisors (Allen, 2008) as well as their leadership skills. They should be encouraged to use a people-orientated leadership style. This will help them to demonstrate support and caring and will also allow twoway communication between supervisors and subordinates (Eisenberger, Rexwinkel, Lynch, \& Rhodes, 2001). In addition, they should be coached on how to conduct performance appraisals and on how to provide effective performance feedback to facilitate employee skills development (Kim, 2012).

Employers can demonstrate that they value their employees by providing competitive and fair compensation packages. Positive feedback and recognition for value-adding contributions by employees as well as fair rewards increase retention (Allen, 2008; Allen, et al., 2003; Rhoades \& Eisenberger, 2002). Competitive and fair compensation packages are also crucial to decrease dissatisfaction and to minimize the attractiveness of alternative employment. Research findings have consistently indicated that high pay and generous benefit packages as well as on-site childcare and family-friendly programs reduce turnover rates (Haines, et al., 2010; Kim, 2012). Variable compensation (e.g., skillbased pay, pay-for-competencies, individual incentives, profit sharing and share ownership plans) could be considered as an alternative to more traditional base-pay systems. These flexible systems allow an organization to respond to alternative compensation offers (Azfar \& Danninger, 2001; Blakemore, Low \& Ormiston, 1987). Another alternative that could be useful in the banking sector is performance-based compensation. Sturman, Boudreau and Gerhart (2003) found that performance-based compensation increases retention among high performers and decreases retention among low performers. It is argued that performance-based pay leads to financial uncertainty among lower level employees with in turn leads to turnover (Batt, Colvin \& Keefe, 2002).

An examination of the employee turnover profile of an organization can be used to recognize particular demographic groups and turnover hotspots within the organisation (Lynch \& Tuckey, 2008:8). Information of this nature could then be used to guide the development of appropriate interventions to minimize turnover. The turnover profile of an organization is determined by calculating the overall employee turnover rate in an organization as well as the turnover rates for employees on different organizational levels and for different age and gender groups (CIPD, 2004).

\subsection{Conclusion}

It is evident that personal factors as well as job satisfaction and dissatisfaction are important determinants of employee turnover. It could be argued that employees in Limpopo Province would not seek employment elsewhere in greater metropolitan areas in South Africa if their job needs and expectations can be met within the province. However, South African banking CEOs only identified organization wide hygiene factors (development opportunities, remuneration and working hours) as the major causes of employee turnover in the banking sector. They recommend staff development opportunities, competitive remuneration and flexible working hours to manage high turnover in the sector (Grosskopf \& Atherman, 2011). Pettijohn, Pettijohn \& Pettijohn (2004) found that work environment has little impact on banking employees' job satisfaction and turnover. However, the findings of a study by Bajpai and Srivastava (2004) indicate that in the Indian banking sector an insecure job environment as well as a lack of scope for advancement opportunities lead to job dissatisfaction and employee turnover. Research findings by Harman, et al. (2009) indicate that perceptions of job availability were not significant predictors of employee turnover in the Albanian banks. Research findings cited by Springer (2011) indicate that low salaries, heavy workloads, job insecurity and stress contribute to job dissatisfaction and turnover among banking employees.

Empirical evidence is therefore needed to determine if dissatisfaction with organization wide hygiene factors is the only determinant of employee turnover in the banking sector in Limpopo Province or if other factors also contribute to turnover among banking employees in the region. 


\section{Method of Research}

\subsection{Population and Sample}

A cross-sectional mixed method design was employed to gather primary data on turnover amongst banking employees from the target population in a relative short period of time. Only one commercial bank in Limpopo Province was willing to participate in the study on condition that the name of the bank would not be disclosed. That bank has a staff complement to 555 employees.

A custom-made, semi-structured questionnaire was administered to a sample of 30 employees. A minimum sample size of $5 \%$ was selected due to time and financial constraints. Stratified sampling was used to obtain a greater degree of representation and to decrease sampling error. This was followed by a semi-structured interview with the Human Resource manager, as a key informant. The last phase of the data collection process consisted of a focus group discussion. A total of eight employees - two from each of the four organizational levels in the bank - participated in the focus group on a voluntary basis.

The Human Resource manager of the target organization sent a memorandum to all branch managers to inform them, and in turn their staff members, of purpose of the study. All participants were informed that their identities would be kept confidential, that the information obtained would be used for research purposes only and that grouped data would be reported.

\subsection{Instrumentation}

The biographical section of the questionnaire includes close-ended items on gender and job position. The rest of the questionnaire consists of both open-ended and close-ended items to identify the causes and impact of employee turnover. Participants also expressed their opinions about the impact of employee turnover on a four-point Likert-type response scale, varying from very high $(v a l u e=4)$ to very low (value $=1)$. Questionnaires were distributed by hand. In order to prevent a poor return rate and to answer any queries about questionnaire items, a researcher was available during questionnaire completion. Questionnaires were collected immediately after they had been completed.

The Human Resource manager was interviewed on the causes of turnover from a managerial perspective. An hour-long focus group discussion which focused on the cause of employee turnover was conducted. A focus group discussion was employed because it is deemed as a valuable resource to highlight the reasons why employees leave an organization (Allen, 2008; 17). Both the key-informant interview and the focus group discussion were audio-taped, transcribed and stored electronically.

Secondary data on employee turnover rates and the financial costs to replace employees was collected from the annual report of the bank for the whole target population. Archival data was used because the study was conducted in April and complete statistics on the movement of employees were no available for the whole year.

\subsection{Data analysis}

Both statistical and non-statistical techniques were used to analyse data. Data obtained from different methods and respondents were combined to identify patterns of convergence and divergence in the data. The Statistical Package for Social Sciences (SPSS v. 21.0) was used to calculate descriptive statistics (frequency and percentage).

The total voluntary and involuntary turnover rates and turnover rates based on position, gender and age groupings were calculated by determining the ratio of the total number of leavers over the year to the average total number employed over the same period multiplied by 100 as recommended by the Chartered Institute of Personnel and Development (CIPD, 2004:2).

Open-ended questionnaire items were segmented, listed and numbered. The segments were then categorized. Close-end questionnaire responses were coded without any additional segmentation of the content. All the data obtained were then combined and summarized to inform the objectives of the study.

\section{Findings}

\subsection{Sample composition}

It can be seen from Table 1 that the majority of employees in the sample work on the lower management and operative 
levels and that the sample was balanced in terms of gender.

Table 1. Stratified Sample Size based on Position and Gender

\begin{tabular}{|l|c|c|c|c|}
\hline Organizational level & Population & Percentage required & No. of participants & Proportion males to females \\
\hline Top and senior management & 1 & $0 \%$ & 0 & 0 \\
\hline Middle management & 68 & $12 \%$ & 4 & $2: 2$ \\
\hline Lower management & 192 & $35 \%$ & 10 & $5: 5$ \\
\hline Operative employees & 294 & $53 \%$ & 16 & $8: 8$ \\
\hline Total & $\mathbf{5 5 5}$ & $\mathbf{1 0 0} \%$ & $\mathbf{3 0}$ & $15: 15$ \\
\hline
\end{tabular}

\subsection{Employee turnover rates and causes}

The overall turnover rate and turnover rates for different grouping in the target population is given in Table 2.

Table 2. Employee Turnover Rates based on Position, Age and Gender

\begin{tabular}{|l|l|c|c|c|}
\hline Particulars & Variables & Frequency & Terminations & Turnover rate (\%) \\
\hline \multirow{4}{*}{ Organizational level } & Top and senior management & 1 & 0 & 0.00 \\
& Middle management & 68 & 2 & 2.94 \\
& Lower management & 192 & 27 & 14.06 \\
& Operative employees & 294 & 50 & 17.01 \\
\hline \multirow{2}{*}{ Age group } & $20-39$ & 443 & 64 & 14.45 \\
& $40-$ over 69 & 112 & 15 & 13.16 \\
\hline \multirow{2}{*}{ Gender } & Male & 142 & 15 & 10.56 \\
& Female & 413 & 64 & 15.50 \\
\hline Overall turnover rate & & & & 14.23 \\
\hline
\end{tabular}

The turnover rate of employees of the Bank of America before interventions were implemented to decrease the turnover rate was 48\% (Springer, 2011). After interventions were introduced by the Bank of America the turnover rate dropped to 24\% (Nelson, 2007).

It is evident from Table 2 that the overall turnover rate in the bank under investigation is very low $(14.23 \%)$ compared to a bank in a developed country. Focus group participants in the study attribute the low turnover rate in the target organization to a high level of job satisfaction. They indicated that the bank allows employees opportunities for more challenging work, autonomy and considerable levels of responsibility.

The results reported in Table 2 show that two personal factors, namely organizational level, and to a lesser extent, gender account for turnover in the target population. It can be seen from Table 2 that the turnover rate for lower management (14.06\%) and operative levels (17.01\%) is much higher compared to the rate of turnover for top, senior and middle management (2.49\%). However, the turnover rate for age groupings in the sample is almost equally distributed. This finding contradicts previous research findings cited in this article that the turnover rate for younger employees is usually much higher than the turnover rate for older employees.

The difference in the turnover rate for females $(15.50 \%)$ is somewhat higher compared to the rate of turnover for their male counterparts (10.56\%). Black Economic Empowerment (BEE) legislation in South Africa as well as the bank's BEE Program could account for the relatively low turnover of female employees. Black Economic Empowerment (BEE) legislation was promulgated to give previously disadvantaged groups (Blacks, women and persons with disabilities) economic opportunities not previously available to them (Emkes, 2012). Three of the seven main criteria upon which the empowerment credentials of businesses are assessed are management representations, employment equity and skills development (Ponte, Roberts \& Van Sittert, 2007). Industry specific empowerment charters have been developed to implement BBE in different industrial sectors, including the financial sector (Moyo \& Rohan, 2006). As a result of this, the four largest commercial banks in South Africa (ABSA, FNB, Nedbank and Standard Bank) as well as smaller banks have BEE programs in place.

Primary data from the questionnaire, focus group and key informant interview highlight other major factors that account employee turnover in the bank. These causes of turnover are depicted in Table 3. 
Table 3. Causes of Employee Turnover

\begin{tabular}{|c|c|c|}
\hline Method & Turnover type & Cause \\
\hline Interview & Voluntary & $\begin{array}{l}\text { Better job offers elsewhere } \\
\text { Black Economic Empowerment (BEE) legislation and program }\end{array}$ \\
\hline Focus group & Voluntary & $\begin{array}{l}\text { BEE legislation and program } \\
\text { Better job offers elsewhere } \\
\text { Non-competitive compensation } \\
\text { Lack of promotion opportunities }\end{array}$ \\
\hline Questionnaire & Voluntary & $\begin{array}{l}\text { Better job offers elsewhere } \\
\text { Non-competitive compensation } \\
\text { Lack of promotion opportunities }\end{array}$ \\
\hline
\end{tabular}

It can be seen from Table 3 that dissatisfaction with compensation and promotional opportunities and the availability of alternative employment are major causes of voluntary employee turnover in the bank. These findings support observations by South African CEOs that a lack development opportunities and non-competitive remuneration account for job dissatisfaction among banking employees. However, participants in the present study are not dissatisfied with their working hours as indicated by the CEOs.

The human resource manager and focus group participants also highlighted BEE legislation and the bank's BEE Program as major causes of employee turnover. It could be argued BEE legislation and the bank's BEE Program could increase the job dissatisfaction and turnover of white employees because their promotional opportunities are limited.

\subsection{The impact of employee turnover}

On average it costs R500 000 to recruit a top manager, R300 000 to recruit a middle manager, R150 000 to recruit a lower manager and R 60000 to recruit an operative employee in the target organization as is evident from Table 4.

Many of the respondents who complete the questionnaire (60\%) perceived that employee turnover has a high impact on the efficiency, productivity and service delivery of the bank as is indicated in Table 5.

Table 4: Employee Recruitment Costs

\begin{tabular}{|c|c|}
\hline Organizational level & Average personnel cost \\
\hline Top \& senior management & R500 000 \\
\hline Middle management & R300 000 \\
\hline Lower management & R150 000 \\
\hline Operative employees & R60 000 \\
\hline Total & R1010 000 \\
\hline
\end{tabular}

Table 5. Impact of Employee Turnover on Efficiency, Productivity and Service Delivery

\begin{tabular}{|c|c|c|}
\hline Impact & Frequency & Percentage of respondents (\%) \\
\hline High & 18 & 60.0 \\
\hline Low & 12 & 40.0 \\
\hline Total & 30 & 100.0 \\
\hline
\end{tabular}

\section{Conclusions}

The purpose of this article was to explore employee turnover in the banking sector in Limpopo Province and to recommend interventions for the retention of banking employees in general and human capital in particular. The findings highlighted three personal factors and four hygiene factors that lead to voluntary employee turnover in the target organization. The research contributes to a better understanding of factors that cause employee turnover in the sector in the region and show that employee turnover is a complex issue.

Contrary to what was expected the findings of the present study show that the employee turnover rate in the banking group is quite low. Despite this important finding employees feel that turnover has a severe impact on efficiency, productivity and service of the bank under investigation. 
Turnover is higher in the lowest organizational level where less complex skills are demanded from job holders. This could be beneficial because in the future the need for lower level skills in the banking sector would diminish as indicated by Archer (2008). On the other hand, for this particular bank even a loss of lower level skills as well as intermediate skills and competencies on the lower management level could be dysfunctional given that all types of skills is a scarce commodity in Limpopo Province.

The bank should take particular care to retain and develop its female employees and to cater for their specific needs. The retention of younger employees should also be a priority to prevent an increase in the turnover rate of these employees in future. Younger employees (Generation Y, born between 1961 and 1979) value unexpected rewards, learning opportunities, recognition, feedback and regular interaction with their supervisors (Nel, et al., 2011). The bank should cater for these needs of its younger employees in order to retain them.

In addition, it is recommended that the bank should consider interventions to decrease employees' dissatisfaction with compensation and opportunities for promotion to counter attractive opportunities offered by other employers in the region and elsewhere in the country. This could impact positively on replacement costs, in particular recruitment costs, for employees on all organizational levels in the bank. The best way to counteract better job offers is to offer competitive compensation packages (Grissom, et al., 2012; Ito, 2003).

Another way to increase employee retention is to take note of the career development needs of employees. The bank's BEE program should be used to train and develop employees, in particular female employees, to prepare them for promotion. Higher level job vacancies should be filled internally instead of recruiting employees externally. This could counteract the loss of employees as a result of BEE legislation and decrease recruitment costs. Incentives such as job enrichment and job enlargement and performance bonuses should be provided for employees who plan to leave the bank as a result of $B E E$ initiatives that curb their promotional aspirations. Rewards for value-adding contributions in the form of positive feedback and recognition could also increase retention (Allen, 2008). Moreover, employees should continuously be reminded that the bank caters for their need for challenging work, autonomy and considerable levels of responsibility. This could shift their focus from compensation and promotion to re-affirmation that the bank does satisfy their intrinsic job needs (Bertelli, 2007).

The findings of the present study are limited to one bank group in Limpopo Province. The sample used was also relatively small. Further in-depth research is needed to unpack the expectations and needs of employees at various organizational levels, of employees in different age groups and of female employees that impact on job satisfaction and dissatisfaction in the banking sector. The expectations and needs of diverse groups in the sector also warrant further research. Another fruitful research possibility is to compare the expectations and needs of employees in other banks in Limpopo Province and in different regions in South Africa.

\section{References}

Abbasi, S. M. \& Hollman, K. W. (2000). Turnover: the real bottom line. Public Personnel Management, 29 (5), 333-342.

Allen, D. G. (2008). Retaining talent: A guide to analysing and managing employee turnover. USA: SHRM Foundation.

Allen, D. G., Sore, L. M. \& Griffith, R. W. (2003). The role of perceived organizational support and supportive human resource practices in the turnover process. Journal of Management, 29 (1), 99-118.

Amah, O. E. (2009). Job satisfaction and turnover intention relationship: the moderating effect of job role centrality and life satisfaction. Research and Practice in Human Resource Management, 17(1), 24-35.

Archer, S. (2008). The financial services sector and its skills development issues relevant to the South African economy. Department of Labour, S.A.

Azfar, O. \& Danninger, S. (2001). Profit-sharing, employment stability, and wage growth. Industrial and Labor Relations Review, 54 (3): 619-630.

Ballester, M. B., Livnat, J. \& Sinha, N. (2012). Labor costs and investments in human capital. Journal of Accounting, Auditing and Finance, 17(4): 351-373.

Bajpai, N. \& Srivastava, D. (2004). Sectorial comparison of factors influencing job satisfaction in Indian baking sector. Singapore Management Review, 26 (2): 89-99.

Batt, A., Colvin, J .S. \& Keefe, J. (2002). Employee voice, human resource practices, and quit rates: evidence from the telecommunications industry. Industrial and Labor Relations Review, 55 (4): 573-94.

Bertelli, A.M. (2007). Determinants of bureaucratic turnover intentions: evidence from the Department of the Treasury. Journal of Public Administration Research, 17 (2): 235-258.

Blakemore, A. E., Low, S. A. \& Orminston, M. B. (1987. Employment bonuses and labor turnover. Journal of Labor Economics, 5 (4): 124-135.

Breaugh, J.A. \& Starke, M. (2000). Research on employee recruitment: so many studies, so many remaining questions. Journal of Management, 26, 405-434. 
Campbell, B. A., Coff, R. \& Kryscynski, D. (2012). Rethinking sustained competitive advantage from human capital. Academy of Management Review, 37 (3): 376-395.

Choi, S. L. \& Lee, Y. T. (2011) .Relationship between leadership style, job satisfaction and employees' turnover intentions: a literature review. Research Journal of Business Management, 5 (3): 91-100.

Choi, S. L., Musibau, A. A., Khalil, M. N. \& Ebi, S. S. (2012). The approaches to increase employees' loyalty: a review on employees' turnover models. Australian Journal of Basic \& Applied Science, 6 (10): 282-291.

CIPD. (2004). Employee turnover and retention. London: CIPD.

Cotton, J. L. \& Tuttle, J. M. (1986). Employee turnover: a meta-analysis and review of implications for research. Academy of Management Review, 11: 55-70.

Eisenberger, R., Armeli, S., Rexwinkel, B., Lynch, P. D. \& Rhodes, L. (2001). Reciprocation of perceived organizational support. Journal of Applied Psychology, 86 (1), 42-51.

Emkes, W. (2012). Black economic empowerment and South Africa. Contemporary Review, 294 (1750): 200-208.

Griffith, R. W. \& Horn, P. W. (2001). Retaining valued employees. Thousand Oaks, CA: Sage.

Griffith, R. W., Horn, P. W. \& Gaertner, S. (2000). A meta-analysis of antecedents and correlates of employee turnover: update, moderator tests, and research implications for the next millennium. Journal of Management, 26 (3), 463-488.

Grissom, J. A., Nicholson-Crotty, J. \& Keiser, L. (2012). Does my boss's gender matter? Explaining job satisfaction and employee turnover in the public sector. Journal of Public Administration Research \& Theory, 22 (4): 649-673.

Grosskopf, J. \& Atherman, K. (2011). Strategic and emerging issues in South African banking. Accountancy SA, October 1, 2011 Issue.

Haines, V. Y., Jalette, P. \& Larose, K. (2010). The influence of human resource management practices on employee voluntary turnover rates in the Canadian non-governmental sector. Industrial and Labor Relations Review, 63 (2): 228-246.

Harman, W. S., Blum, M., Stefani, J. \& Taho, A. (2009). Albanian turnover: is the job embeddedness construct predictive in an Albanian context? Journal of Behavioral and Applied Management, 10 (2): 192-205.

Herzberg, F. (1968). One more time. How do you motivate employees? Harvard Business Review, 46 (1): 53-62.

Herzbarg, F., Mauser, B. \& Snyderman, B. B. (1959).T he Motivation of Work. (2nd Ed). New York: John Wiley and Sons.

Horn, P. W., Griffith, R. W. \& Sellaro, C. L. (1984). The validity of Mobley's (1977) model of employee turnover. Organizational Behavior and Human Performance, 34 (2): 141-74.

Houkes, I., Janssen, P. M., De Jonge, J. \& Bakker, A. B. (2003). Specific determinants of intrinsic work motivation, emotional exhaustion and turnover intention: a multi-sample longitudinal study. Journal of Occupational and Organizational Psychology, 76, 427-450.

Ito, J. K. (2003). Career mobility and branding in the Civil Service: an empirical study. Public Personnel Management, 32 (1):1-21.

Kabungaidze, T., Mahlatshana, N. \& Ngirande, H. (2013). The impact of job satisfaction and some demographic variables on employee turnover intentions. International Journal of Business Administration, 4 (1); 53-65.

Kammeyer-Mueller, J. D. \& Wanberg, C. R. (2003). Unwrapping the organizational entry process: disentangling multiple antecedents and their pathways to adjustment. Journal of Applied Psychology, 88: 779-794.

Kasimati, M. (2011). Job satisfaction and turnover under the effect of person-organization fit in Albanian public organizations. Journal for East European Management Studies. 16 (4): 315-337.

Kellough, J. E. \& Haoran, L. (1993). The paradox of merit pay in the public sector: persistence of a problematic procedure. Review of Public Personnel Administration, 13 (2):45-64.

Kim, S. (2012). The impact of human resource management on state government IT employee turnover intentions. Public Personnel Management, 41 (2): 257-279.

Limpopo Growth and Development Strategy, 2004-2014. [online] Available: http://led.co.za/sites/led.co.za/files/cabinet/orgnameraw/document/2011/limpopo_growth_and_development_strategy.pdf

Liu, D., Mitchell, T. R., Lee, T. W., Holtom, B. C. \& Hinkin, T. R. (2012). When employees are out of step with co-workers: how job satisfaction trajectory and dispersion influence individual - and unit-level voluntary turnover. Academy of Management Journal, 55 (6): 1360-1380.

Long, C. S., Ajagbe, M.A., Nor, K. M. \& Suleiman, E. S. (2012). The approaches to increase employees' loyalty: a review on employees' turnover models. Australian Journal of Basic and Applied Sciences, 6(10): 282-291.

Lynch, J. \& Tuckey, M. (2008). The police turnover problem: fact or fiction. International Journal of Police Strategies and Management, 31(1): 6-18.

Meier, K. J. \& Hicklin, A. (2008). Employee turnover and organizational performance: testing hypothesis from classic public administration. Journal of Public Administration Research, 18 (4): 573-590.

Metcalfe, B. 2011. Unlocking opportunities: strategic and emerging issues in South African banking 2011. Accountancy SA, June 30. [online] Available: Issue.www.pwc.com/za/en_Za/za/assests/pdf/SA-Banking-2011.pdf

Moyo, T. \& Rohan, S. (2006). Corporate citizenship in the context of the financial services sector: what lessons from the financial sector charter? Development Southern Africa, 23(2): 281-303.

Nel, P. S., Erasmus, B. J. \& Swanepoel, B. J. (2001). Human resources management. Cape Town: Oxford University Press.

Nel, P. S., Van Dyk, P. S., Haasbroek, G .D., Schultz, H. B., Sono, T. \& Werner, A. (2011). Human resources management. (8th Ed). Southern Africa: Oxford University Press.

Nelson, B. (2007). Bank of America: improving turnover. Corporate Meetings and Incentives, 26 (3): 34-36.

Oosthuizen, M. \& Naidoo, P. (2004). Internal migration to the Gauteng Province. Development Policy Research Unit, December 2004. Working Paper 04/88. 
[online] Available: http://www.queensu.ca/samp/migrationresources/Documents/Oosthuizen_internal.pdf

Pettojohn, C. E., Pettijohn, L. S. \& Pettijohn, J. B. (2004). Supermarket branch banks and traditional banks: an evaluation of differences in employees' attitudes regarding product offerings, job satisfaction and turnover. Journal of Financial Services Marketing, 9 (1): 11-21.

Ponte, S., Roberts, S. \& Van Sittert, L. (2007). 'Black economic empowerment', business and the state in South Africa.Development and Change, 38 (5): 933-955.

Porter, L. W. \& Steers, R. M. (1973). Organizational, work, and personal factors in turnover in employee turnover and absenteeism. Psychological Bulletin, 80 (2): 151-176.

Radebe, S. (2009). A task that's achievable. [online] Available: http://free.financialmail.co.za/report09/trade09/btrade.htm

Rhoades, L. \& Eisenberger, R. (2002). Perceived organizational support: a review of the literature. Journal of Applied Psychology, 87(4): 698-714.

Seymour, E. \& Buscherhof, R. J. (1991). Sources and consequences of satisfaction and dissatisfaction in nursing: findings from a national sample. International Nursing Studies, 28, 109-124.

Shahzad, K., Abbas, M. \& Bashir, S. (2011). Antecedents of turnover and absenteeism: evidence from public sector institutions of Pakistan. Interdisciplinary Journal of Contemporary Research in Business, 2 (9): 108-120.

Shaw, J. D., Gupts, N. \& Delery, J. E. (2005). Alternative conceptualizations of the relationship between voluntary turnover and organizational performance. Academy of Management Journal, 84: 50-68.

Sherman, A. W. \& Bohlander, G. W. (1992). Managing human resources. Cincinnati: South-Western Publishing Co.

Sing, D. (2012). Human resource challenges confronting the senior management service of the South African public service. Public Personnel Management, 41 (2): 379-388.

Singh, P. \& Loncar, N. (2010). Pay satisfaction, job satisfaction and turnover intent. Industrial Relations, 65(3): 470-490.

Springer, G. J. (2011). A study of job motivation, satisfaction, and performance among bank employees. Journal of Global Business Issues. 5 (1): 29-42.

Struman, M.C., Trevor, C.O., Boudreau, J.W. \& Gerhart, B. (2003). Is it worth it to win the talent war? Evaluating the utility of performance-based pay.Personnel Psychology, 56, 997-1035.

Sulaiman, O. A. \& Ogunsina, S. O. (2011). Influence of supervisory behaviour and job stress on job satisfaction and turnover intention of police personnel in Ekiti State. Journal of Management and Strategy, 2 (3): 13-20.

Tariq, M., Ramzan, M. \& Raiz, A. (2013).The impact of employee turnover on the efficiency of the organization.Interdisciplinary Journal of Contemporary Research in Business, 4 (9):700-711.

Van Der Merwe, R. \& iller, S. (1988). Measuring absence and labour turnover: a practical guide to recording and control. Johannesburg: Lexicon.

Walsh, K. \& Taylor, M. S. (2007). Developing in-house careers and retaining management talent what hospitality professionals want from their jobs. Cornell Hospitality Quarterly, 48 (2), 163-182.

Wang, Y., Yang, C. \& Wang, K. (2012). Comparing public and private employees job satisfaction and turnover. Public Personnel Management 41 (3): 557-573.

Yücel, I. (2012). Examining the relationships among job satisfaction, organizational commitment, and turnover intention: an empirical study. International Journal of Business and Management, 7 (20): 41-58.

Zeki, G., Engin, A. Y. \& Selim, K. (2012). A military application of human capital management: military pilot turnover. International conference of scientific paper AFASES, Brasov, 24-26 May 2012. 